\title{
Low prevalence of nonconservative mutations of serum and glucocorticoid-regulated kinase (SGK1) gene in hypertensive and renal patients
}

\author{
Nadja Trochen ${ }^{1}$, Santhirasekaran Ganapathipillai ${ }^{1}$, Paolo Ferrari ${ }^{1,2}$, Brigitte M. Frey ${ }^{1}$ and \\ Felix J. Frey ${ }^{1}$ \\ ${ }^{1}$ Division of Nephrology and Hypertension, University Hospital, Berne, Switzerland and ${ }^{2}$ Department of Nephrology, \\ Fremantle Hospital, University of Western Australia, Perth, Australia
}

\begin{abstract}
Background. The serum- and glucocorticoid-regulated kinase $(S G K 1)$ gene is an important mediator of aldosterone action, regulating the expression of the renal epithelial $\mathrm{Na}^{+}$channel. In renal failure, blood pressure (BP) is markedly salt-dependent and increases with decreasing renal function. Mutations of the $S G K 1$ gene affecting phosphorylation could be responsible for salt-mediated increases in BP and hypertensionrelated progression to end-stage renal disease (ESRD). Methods. The $S G K 1$ gene was analysed for mutations in the exons $4,5,8$ and $10-12$, because of potential phosphorylation sites, in 591 subjects, including 311 ESRD patients (either dialysis or transplanted). In addition, an intron 6 single-nucleotide polymorphism (SNP) described previously was also investigated in this study. Genotyping was performed either by using a strategy based on single strand conformation polymorphism analysis of polymerase chain reaction (PCR) products and subsequent direct sequencing of identified gel shift variants or by using high throughput $5^{\prime}$ nuclease allelic discrimination assay.

Results. Two SNPs in coding regions of $S G K 1$ potentially influencing the phosphorylation of Sgk1 were identified. Both SNPs were synonymous. The prevalence of the first variant, a previously reported SNP at codon 240 in exon 8, did not differ between ESRD patients $(16.3 \%)$ and controls $(15.7 \%)$. There was no association between the SNP in exon 8 and either BP within the control population or progression of renal disease in the ESRD population. The second SNP at codon 398 in exon 12 was identified in one patient only. Intron 6 and exon 8 SNPs were in strong linkage disequilibrium, but did not show any association with either BP or renal diseases.
\end{abstract}

Correspondence and offprint requests to: Felix J. Frey, MD, Division of Nephrology and Hypertension, Inselspital, University of Berne, Freiburgstrasse 15, 3010 Berne, Switzerland.

Email: felix.frey@insel.ch
Conclusions. Based on statistical analysis homozygosity for nonconservative mutations in the coding region of the $S G K 1$ gene is estimated at $<1 / 300000$ when a white Caucasian population is considered, arguing against an important role of mutations of this coding region in hypertension and hypertension-associated progression of renal disease.

Keywords: end-stage renal disease; genetics; glucocorticoids; hypertension; SGK1

\section{Introduction}

The epithelial sodium $\left(\mathrm{Na}^{+}\right)$channel $(\mathrm{ENaC})$ located in the apical membrane of renal aldosterone-responsive epithelia, plays an essential role in controlling the $\mathrm{Na}^{+}$ balance of extracellular fluids and hence blood pressure (BP) $[1,2]$. The regulation of $\mathrm{ENaC}$ involves a variety of hormonal signals such as aldosterone, vasopressin and insulin [3]. Among regulatory proteins found in recent years the ubiquitin-protein ligase Nedd4-2 negatively controls $\mathrm{ENaC}$ cell surface expression, and the serum glucocorticoid-inducible kinase 1 (Sgk1) acts as an aldosterone- and insulin-dependent positive regulator of $\mathrm{ENaC}$ density at the plasma membrane [4].

Sgk1 was identified in 1993 as an immediate early gene whose mRNA levels increase dramatically within 30 min when cells are exposed to serum or glucocorticoids, or both [5]. The inactive protein Sgk1 is activated by phosphorylation in response to several agonists through a signalling cascade that includes PI3K and the protein kinases PDK1 and PDK2 [6,7]. Using in vitro mutagenesis to substitute serine for asparagine at codon 422 of SGK1, Park et al. [7] showed that Sgk1 becomes fully active under basal conditions. Since Sgk1 plays an important role in activating ion channels, this kinase is crucial in regulating processes 
such as cell survival, neuronal excitability and renal $\mathrm{Na}^{+}$excretion [8]. Therefore, the $S G K 1$ gene could be a candidate for abnormal BP regulation and possibly hypertension. Recently, Busjahn et al. [9] showed a significant association of the SGK1 gene locus to diastolic BP in twins. There was an association between two single-nucleotide polymorphisms (SNPs) in exon 8 and intron 6 and BP [9]. In patients with renal disease BP increases with decreasing glomerular filtration rate, regardless of the primary cause of the renal disease [10]. Hypertension in renal failure shows a marked salt-dependency and is one of the important contributors for the progressive increase in BP associated with the loss of renal function [11]. Therefore, a genetically determined predisposition to renal sodium retention could aggravate the sodium retention observed in renal failure and play an important role in patients suffering from end-stage renal disease (ESRD). The aim of the present genetic association study was to assess whether mutations of $S G K 1$ affecting phosphorylation sites of the gene product can be identified in unselected patients with hypertension and patients with ESRD. We also analysed whether the reported association of exon 8 and intron 6 with BP in normotensive twins [9] is predictive of hypertension or renal failure in unrelated subjects.

\section{Subjects and methods}

Study subjects were 311 patients with ESRD from our Division of Nephrology and Hypertension (University Hospital of Berne, Switzerland) and 280 control subjects without renal disease as described previously [12]. Ethnicity was homogeneous, with $88 \%$ subjects of Swiss German, $9 \%$ Mediterranean and 2\% Asian origin. Of the control subjects, 167 were healthy normotensive individuals and 113 had hypertension. Definitions, characteristics and demographic data of control subjects and ESRD patients were described previously [13].

\section{Genotyping}

Mutation detection in $S G K 1$ was performed in all 591 subjects using polymerase chain reaction (PCR) to amplify exon 4 (phosphorylation at serine 78), 5 (putative ATP binding site), 8 (phosphorylation by PDK1), 10 (interaction of Sgk1 with NEDD4-2), 11 (phosphorylation by PKA) and 12 (phosphorylation by PDK2) [6,14-16]. Primers and cycle conditions are described in Table 1. In addition, intron 6 was amplified as described below [9]. The reactions were performed with a concentration of $1 \times$ PCR buffer in a final volume of $25 \mu 1$, with 1.5-4.5 mM $\mathrm{MgCl}_{2}, 1.5 \mathrm{U}$ AmpliTaq-Gold-Polymerase (PE Biosystem, Foster City, CA, USA), 0.2-0.3 mM of each dNTP and $0.4 \mathrm{mM}$ of each primer. DNA was used in a concentration of $100 \mathrm{ng}$ and amplified with a thermocycler PCR system 9700 (GeneAmp ${ }^{\circledR}$ by Applied Biosystem). PCR products were analysed using single strand conformational polymorphism (SSCP) using an established method [12]. Sequence changes were detected by band shift on the gel. Variants were purified using QIA-quick PCR purification columns (Qiagen, Chatsworth, CA, USA) according to the supplier and sequenced by Microsynth (Balgach, Switzerland) on an ABI 373A automated sequencer using the same primers as for PCR. Obtained sequences were compared with $S G K 1$ gene sequence (GenBank gi 18563240).

Genotyping for intron 6 SNP was performed by allelic discrimination using $5^{\prime}$ nuclease assay. The target-specific primers and $\operatorname{TaqMan}^{\circledR}$ MGB probes were sense $5^{\prime}$-GGCCA CTTCCTGCAGTTGT-3', antisense 5'-TGCAGGAGACA GAACAAAGTCATTC-3'. As a reporter at the $5^{\prime}$ end of the TaqMan ${ }^{\circledR}$ MGB probe, FAM ${ }^{\circledR}$ was used for wild-type T allele (5'-FAM-ATTAAATTCATTTGCAACCC-3') and $\mathrm{VIC}^{\circledR}$ was used for variant $\mathrm{C}$ allele $\left(5^{\prime}\right.$-VIC-ATTAAATT CATTCGCAACCC-3'). PCR was performed with a reaction volume of $25 \mu \mathrm{l}$ including $12.5 \mu \mathrm{l}$ of TaqMan ${ }^{\circledR} 2 \times$ Universal PCR Master Mix (Applied Biosystems), $0.6 \mu \mathrm{l}$ of assay mix and $5 \mu \mathrm{l}$ of genomic DNA at a concentration of $1-10 \mathrm{ng} / \mathrm{ml}$. The PCR cycling conditions were: one cycle at $50^{\circ} \mathrm{C}$ for $2 \mathrm{~min}$, followed by one cycle at $95^{\circ} \mathrm{C}$ for $10 \mathrm{~min}$, and 40 cycles at $95^{\circ} \mathrm{C}$ for $15 \mathrm{~s}$ and $60^{\circ} \mathrm{C}$ for $1 \mathrm{~min}$. Allelic discrimination was carried out by measuring fluorescence intensity at the endpoint by an ABI PRISM ${ }^{\circledR}$ Sequence Detection System 7000 (Applied Biosystems). The results of the measurement

Table 1. Primers and conditions used in this study

\begin{tabular}{|c|c|c|c|c|c|}
\hline Exon & Primers & & Cycles $^{\mathrm{a}}$ & $\begin{array}{l}\text { Annealing } \\
\text { temperature }\left({ }^{\circ} \mathrm{C}\right)^{\mathrm{a}}\end{array}$ & $\begin{array}{l}\mathrm{MgCl}_{2} \\
(\mathrm{mM})\end{array}$ \\
\hline 4 & $\begin{array}{l}\text { Sense } \\
\text { Antisense }\end{array}$ & 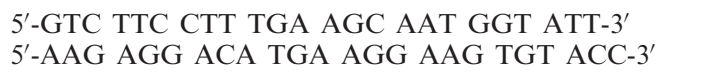 & 32 & 63 & 4.5 \\
\hline 5 & $\begin{array}{l}\text { Sense } \\
\text { Antisense }\end{array}$ & $\begin{array}{l}5^{\prime} \text {-ATG TCC TCT TTT GTA TTC TCC CTG-3' } \\
5^{\prime} \text {-GAT TAT TCA AGG AGT GTC TAC CGC-3' }\end{array}$ & 32 & 58 & 4.5 \\
\hline 8 & $\begin{array}{l}\text { Sense } \\
\text { Antisense }\end{array}$ & $\begin{array}{l}5^{\prime} \text {-TGT GCA ACT ACT TTT CTA TTC ACT TTT-3' } \\
5^{\prime} \text {-TGT GCA ACT ACT TTT CTA TTC ACT TTT-3' }\end{array}$ & 38 & 54 & 4.5 \\
\hline 10 & $\begin{array}{l}\text { Sense } \\
\text { Antisense }\end{array}$ & $\begin{array}{l}5^{\prime} \text {-GCC ATA TGA AAC TTC CAA TTA AGT C-3' } \\
5^{\prime} \text {-AGA CAG GTG CAT TCA ATA AGG G-3' }\end{array}$ & 34 & 60 & 1.5 \\
\hline 11 & $\begin{array}{l}\text { Sense } \\
\text { Antisense }\end{array}$ & $\begin{array}{l}\text { 5'-CTT ATT GAA TGC ACC TGT CTA AA-3' } \\
5^{\prime} \text {-TGA ATT AAA AAT GCC CTT TGG-3' }\end{array}$ & 32 & 62 & 4.5 \\
\hline 12 & $\begin{array}{l}\text { Sense } \\
\text { Antisense }\end{array}$ & $\begin{array}{l}5^{\prime} \text {-CTT GAC AAG AGT GTT TTT CCC TTC- } 3^{\prime} \\
5^{\prime} \text {-ATA AAA TCC TTT AAA ACC AAG CCC-3' }\end{array}$ & 36 & 58 & 3.5 \\
\hline
\end{tabular}

\footnotetext{
${ }^{\text {a }}$ Denaturation at $94^{\circ} \mathrm{C}$ for $30 \mathrm{~s}$, annealing for $30 \mathrm{~s}$ and extension at $72^{\circ} \mathrm{C}$ for $1 \mathrm{~min}$.
} 
were analysed using SDS software (Applied Biosystems) and the genotype was determined.

Amplification of exon 8 failed in one subject and amplification of intron 6 was not successful in five subjects. Thus, the numbers in Tables 3 and 4 do not add up to the expected 591 as predicted by the number of subjects investigated.

\section{Statistical analysis}

Differences between means were assessed by the unpaired $t$-test or ANOVA. For categorical variables the $2 \times 2$ contingency tables by the $\chi^{2}$-test was used. The expected 'disease' frequency for the target population was calculated according to the Hardy-Weinberg equation and an estimate of the probability that, with a given prevalence, mutations are not detected was obtained by the Armitage equation: $Z=(N . p-0.5) /[N \cdot p \cdot(1-p)]^{-2}$, where $p=$ assumed prevalence, $n=$ number of alleles, $N . p$. = expected number of mutations, as previously described [12].

\section{Results}

A total of two synonymous SNPs in coding regions of $S G K 1$ potentially influencing the phosphorylation of Sgk1 were identified (Table 2). The first SNP was found in exon 8 and is identical with a previously reported SNP [9]. The frequency of this $\mathrm{C} \rightarrow \mathrm{T}$ transition at codon 240 in the different study groups is shown in Table 2. The overall prevalence of this SNP in exon 8 of the SGK1 gene was $15.9 \%$, the frequency of the wild-type allele was 0.91 and the frequency of the mutated allele was 0.09 .

The expected frequency of the $S G K 1$ exon 8 genotype, under the assumption of the Hardy-Weinberg equilibrium, did not differ from observed frequencies in ESRD patients and control subjects (Table 2). This genetic polymorphism was also analysed for its relation to the rate of progression of renal disease in ESRD patients and to $\mathrm{BP}$ or the presence or absence of hypertension in the control population. Progression of renal disease in the ESRD population as a whole was not influenced by the $S G K 1$ polymorphism in exon 8
(Table 3). There was no link between the SNP in exon 8 with either systolic or diastolic BP or the presence or absence of hypertension $\left(\chi^{2}=0.346, P=0.556\right)$ within the control population with normal renal function (Table 3). The intron 6 and exon 8 SNPs were in strong linkage disequilibrium, as shown in Table 4. We grouped both the ESRD and control population according to the two SNPs into subjects with exon $8 \mathrm{CT} / \mathrm{CC}+$ intron $6 \mathrm{TT} / \mathrm{CT}$, exon $8 \mathrm{CT} / \mathrm{CC}+$ intron $6 \mathrm{CC}$, and exon $8 \mathrm{TT}+$ intron $6 \mathrm{CC}$ genotypes as previously described [9]. This association analysis did not show any significant or suggestive association of the SGK1 gene locus to systolic and diastolic BP in the control population without ESRD, either with normal or increased BP (Table 5).

The effect of genotype was analysed in relation to the aetiology of renal disease in the ESRD population. Association analysis was performed separately for patients with glomerulonephritis $(N=92)$, interstitial nephritis $(N=46)$, polycystic kidney disease $(N=39)$, diabetes mellitus $(N=30)$, pyelonephritis/vesicoureteral reflux $(N=29)$, nephroangiosclerosis $(N=17)$ and other or unknown aetiologies $(N=42)$. This analysis did not reveal any significant outcome on the prevalence of a given underlying disorder (data not shown). In particular, the incidence of hypertensive nephroangiosclerosis was not different among the described biallelic groups.

The second SNP in the coding region was found in exon 12 and was identified in one patient only. Again, this SNP represented a synonymous mutation, with a $\mathrm{T} \rightarrow \mathrm{C}$ mutation at codon 398 . There were no mutations of SNP in exons $4,5,10$ and 11 detectable in any of the 591 screened patients. We expected to find the polymorphism in exon 10, which has been described in the SNP database (AS 296 $\mathrm{C} \rightarrow \mathrm{T}$, non-synonymous, reference \#rs 1057934), but none of the 591 screened subjects tested positive for it. There were a few additional intronic variants identified as band shift in the SSCP. One was a $G \rightarrow A$ substitution at nucleotide 35 in intron 10 in one subject, another was a $G \rightarrow A$ substitution at nucleotide 40 in intron 10, which was found in two subjects.

Table 2. Identified mutations in the coding and non-coding regions of the SGK1 gene in control subjects and patients with ESRD

\begin{tabular}{|c|c|c|c|c|c|}
\hline & \multirow[t]{2}{*}{ All } & \multirow{2}{*}{$\begin{array}{l}\text { ESRD } \\
\text { Dialysis }\end{array}$} & \multicolumn{3}{|l|}{ Controls } \\
\hline & & & Transplanted & Hypertension & Healthy \\
\hline$N$ & 591 & 96 & 215 & 113 & 167 \\
\hline Exon 4 & - & - & - & - & - \\
\hline Exon 5 & - & - & _- & - & _- \\
\hline \multicolumn{6}{|l|}{ Exon $8 \mathrm{C} \rightarrow \mathrm{T}$ Asp ${ }^{240} / \mathrm{Asp}$} \\
\hline Heterozygous & $81(13.7 \%)$ & $12(12.5 \%)$ & $31(14.4 \%)$ & $15(13.0 \%)$ & $23(13.4 \%)$ \\
\hline Homozygous & $14(2.4 \%)$ & $1(1 \%)$ & $7(3.2 \%)$ & $1(0.9 \%)$ & $5(3.0 \%)$ \\
\hline Exon 10 & - & - & - & - & - \\
\hline Exon 11 & - & - & - & - & - \\
\hline Exon $12 \mathrm{~T} \rightarrow \mathrm{C} \mathrm{Ile}^{398} / \mathrm{Ile}$ & 1 & - & 1 & - & - \\
\hline \multicolumn{6}{|l|}{ Intron $6 \mathrm{~T} \rightarrow \mathrm{C}$} \\
\hline Heterozygous & $182(30.8 \%)$ & $28(29.2 \%)$ & $65(30.2 \%)$ & $36(31.8 \%)$ & $52(31.1 \%)$ \\
\hline Homozygous & $33(5.6 \%)$ & $4(4.2 \%)$ & $17(7.9 \%)$ & $4(3.5 \%)$ & $8(4.8 \%)$ \\
\hline
\end{tabular}


Table 3. Genotype-phenotype analysis of the Asp240Asp variant in exon 8 of the $S G K 1$ gene in control subjects and patients with ESRD

\begin{tabular}{|c|c|c|c|c|}
\hline & \multicolumn{3}{|c|}{ Genotype } & \multirow[t]{2}{*}{$P$-value } \\
\hline & $\mathrm{CC}$ & CT & TT & \\
\hline Control group $(N)$ & 235 & 38 & 6 & \\
\hline \multicolumn{5}{|l|}{$\mathrm{BP}(\mathrm{mmHg})$} \\
\hline Systolic & $140 \pm 23$ & $137 \pm 21$ & $139 \pm 27$ & 0.78 \\
\hline Diastolic & $82 \pm 13$ & $82 \pm 10$ & $79 \pm 6$ & 0.89 \\
\hline ESRD & 260 & 43 & 8 & \\
\hline Age at ESRD (years) & $47 \pm 17$ & $41 \pm 17$ & $43 \pm 15$ & 0.13 \\
\hline Time to ESRD (years) & $11 \pm 9$ & $9 \pm 8$ & $12 \pm 4$ & 0.47 \\
\hline Transplanted subgroup $(N)$ & 177 & 31 & 7 & \\
\hline $\begin{array}{l}\text { Age at transplantation } \\
\text { (years) }\end{array}$ & $43 \pm 12$ & $41 \pm 12$ & $49 \pm 15$ & 0.28 \\
\hline
\end{tabular}

$P$-values are by ANOVA.

Table 4. Linkage disequilibrium between the two SGK1 polymorphisms in intron 6 and exon 8

\begin{tabular}{lllrl}
\hline \multirow{5}{*}{} & \multicolumn{3}{l}{ Intron 6} & \\
\cline { 3 - 5 } & & TT & TC & CC \\
\hline \multirow{2}{*}{ Exon 8 } & CC & $348(59.3 \%)$ & $123(21.0 \%)$ & $20(3.4 \%)$ \\
& CT & $20(3.4 \%)$ & $50(8.5 \%)$ & $11(1.9 \%)$ \\
& TT & $3(0.5 \%)$ & $9(1.5 \%)$ & $2(0.3 \%)$ \\
\hline
\end{tabular}

Table 5. BP in subjects with normal renal function according to the combined exon 8/intron 6 SNP

\begin{tabular}{llll}
\hline Phenotype & $\begin{array}{c}\text { Exon 8 CT/CC } \\
\text { Intron 6 TT/CT }\end{array}$ & $\begin{array}{l}\text { Exon 8 CT/CC } \\
\text { Intron 6 CC }\end{array}$ & $\begin{array}{l}\text { Exon 8 TT } \\
\text { Intron 6 CC }\end{array}$ \\
\hline$N$ & $541(92.7 \%)$ & $\begin{array}{l}31(5.2 \%) \\
21(6.7 \%)\end{array}$ & $2(0.3 \%)$ \\
ESRD & $280(90.0 \%)$ & & \\
$\begin{array}{c}\text { Control } \\
\text { population }\end{array}$ & & & $2(1.2 \%)$ \\
$\begin{array}{l}\text { Normotensive } \\
\text { Hypertensive }\end{array}$ & $155(92.8 \%)$ & $6(3.6 \%)$ & 0 \\
$\begin{array}{l}\text { Systolic BP } \\
\text { (mmHg) }\end{array}$ & & $4(3.5 \%)$ & \\
$\begin{array}{l}\text { Normotensive } \\
\text { Hypertensive }\end{array}$ & $128 \pm 16$ & $119 \pm 13$ & $127 \pm 3$ \\
$\begin{array}{l}\text { Diastolic BP } \\
\text { (mmHg) }\end{array}$ & & $167 \pm 14$ & \\
$\begin{array}{l}\text { Normotensive } \\
\text { Hypertensive }\end{array}$ & $78 \pm 8$ & & $77 \pm 3$ \\
\hline
\end{tabular}

\section{Discussion}

We have analysed the $S G K 1$ gene for association with ESRD in comparison with normal healthy controls and essential hypertensive patients. $S G K 1$ is a logical candidate gene because of its role in maintaining $\mathrm{Na}^{+}$homeostasis. Because a salt-sensitive BP increase occurs frequently in patients with chronic renal failure, contributing to their high prevalence of hypertension, an increased activity of Sgk1 could result in even greater $\mathrm{Na}^{+}$retention and plasma volume expansion. Although two different SNPs in the coding region of the $S G K 1$ gene were identified, they were both synonymous, thus not altering the amino acid sequence. Therefore, our data argue against an important role of nonconservative mutations of the $S G K 1$ gene in a white ESRD population.

Allele frequencies for the $S G K 1$ genotype in exon 8 did not differ significantly between control subjects and ESRD patients or between patients with hypertension and ESRD; moreover, the same polymorphism did not show any significant effect on the rate of progression to renal failure. The same applies for the intron 6/exon 8 SNPs combination, which showed a similar degree of linkage disequilibrium as previously reported [9], but had no reproducible effect on BP in subjects without renal failure. These linked SNPs were also not associated with a particular cause of renal disease in ESRD patients. These observations indicate that these polymorphisms do not have a significant effect on BP in unrelated subjects without renal diseases, do not account for the occurrence of renal diseases per se and are not a determinant of progressive renal failure.

In the last decade great progress has been made in human genetics with the identification of an enormous number of SNPs. However, the impact of these genetic polymorphisms on the understanding of polygenic multifactorial cardiovascular diseases like hypertension has yielded contrasting results [17]. Recently, Busjahn et al. [9] analysed two SNPs within the SGK1 gene in monozygotic (126 pairs) and dizygotic (70 pairs) normotensive twin subjects and parents of dizygotic twins and found significant association of the $S G K 1$ gene locus to diastolic $(P<0.0002)$ and systolic $(P<0.04)$ BP. These authors concluded that the $S G K 1$ gene is relevant to BP regulation and probably to hypertension in man. The relevance of these new SNPs for the whole hypertensive population, however, is unclear. In fact the author did not test these two polymorphisms in hypertensive populations or subgroups of hypertensive patients. In our control population we could not find any association of the SGK1 polymorphic marker in intron 6/exon 8 and $\mathrm{BP}$ in normotensive or hypertensive patients. In the twin study an association between intron 6 and exon 8 SNPs and BP in an independent confirmation sample of 260 subjects was described [9]. However, this effect only applied for $\sim 5 \%$ of subjects with the exon 8 $\mathrm{CT} / \mathrm{CC}$ and intron $6 \mathrm{CC}$ polymorphism compared to $\sim 94 \%$ carriers of the exon $8 \mathrm{CT} / \mathrm{CC}$ and intron 6 TT/CT alleles. Genotype distribution was comparable in our population with $541(92.7 \%)$ subjects having the intron $6 \mathrm{TT} / \mathrm{CT}$ and exon $8 \mathrm{CT} / \mathrm{CC}$ genotype and $31(5.2 \%)$ with the intron $6 \mathrm{CC}$ and exon $8 \mathrm{CT} / \mathrm{CC}$ genotype. This distribution was similar for the patients with or without renal failure. In the control population with the more prevalent genotype, BP values tended to be higher in normotensive but lower in hypertensive subjects, suggesting that these findings do not support the observation from the twin study. This view is also 
supported by experiments using transgenic animals. Wulff et al. [18] showed with the Sgk1 knockout mouse, that the phenotype is far less dramatic than the one observed in the ENaC knockout [19] and the mineralocorticoid knockout mice [20]. This suggests that Sgk1 participates in, but does not fully account for the mineralocorticoid regulation of $\mathrm{ENaC}$. The isoforms Sgk2 and Sgk3 might be able to compensate for the loss, suggesting that loss of function mutations of the $S G K 1$ gene have no influence on the phenotype. Mutations with a gain of function could still lead to hypertension because of the positive regulation of $\mathrm{ENaC}$ density at the plasma membrane [4]. However, in our population no mutations with possible gain of function in the selected gene regions were identified.

The lack of association between the SNPs in SGK1 and $\mathrm{BP}$ in our population could be due to the relatively small sample size, although this did not differ from the confirmation sample described in the former study [9] and illustrates the problems in determining genetic influences in complex traits.

The problem of genetic association studies is not just to test a given polymorphism in a case-control study, or in familial design, but also to determine the relevance of the regulatory transcriptional activity of the candidate gene with the appropriate assessment of all the confounding factors. The function of Sgk1 is not limited to regulation of renal $\mathrm{ENaC}$ activity, but is also relevant for other processes since it is expressed in all human tissues, including pancreas, liver, heart, lung, skeletal muscle, placenta, kidney and brain [21]. Therefore, it seems unlikely that a functionally relevant mutation in such a ubiquitous gene would affect BP regulation only, without showing additional features of functional significance.

The lack of detection of nonconservative mutations in our population could be due to the small sample size analysed. Nevertheless, according to the Armitage equation and for a probability $<5 \%$ of missing any significant mutation causing an altered Sgk1 kinase with a total of 1182 alleles analysed, the estimated prevalence of mutated alleles would be $0.2 \%$. Therefore, the sample size of this population is too small to detect significant mutations in the SGK1 gene for an estimated prevalence of $0.15 \%$ or less. Thus, the expected 'disease' frequency of homozygous SGK1 mutants for the target population, calculated according to the Hardy-Weinberg equation, would be $<1 / 300000$, considering the frequency of a recessive allele of $<1 / 550$.

The findings of the present study argue against an important role of coding regions of Sgk1 in BP regulation and hypertension and in the hypertensionrelated progression of renal diseases. The rate of nonsynonymous, nonconservative coding SNPs of the $S G K 1$ altering the amino acid sequence and therefore generating a kinase with altered activity in this population is low. It seems more likely that abnormal regulation of the $S G K 1$ gene expression, rather than nonconservative mutations in the coding region of the gene itself, may play a role in mediating the effects of Sgk1 in vivo. Homozygosity for nonsynonymous, nonconservative mutations in the coding region of the $S G K 1$ gene of exons 4, 5, 8 and $10-12$ is $<1 / 300000$ when a white Caucasian population is considered, arguing against an important role of mutations of this coding region in hypertension and hypertensionassociated progression of renal disease. Polymorphisms in regulatory regions may be more important than variations in coding regions for multifactorial diseases.

Acknowledgements. This work was supported in part by a grant from the Swiss National Research Foundation (Nos 3100-58889 and 3100-61505).

Conflict of interest statement. There are no potential conflicts of interest that might constitute an embarrassment to any of the authors.

\section{References}

1. Garty H, Palmer LG. Epithelial sodium channels: function, structure and regulation. Physiol Rev 1997; 77: 359-396

2. Rossier BC, Pradervand S, Schild L, Hummler E. Epithelial sodium channel and the control of sodium balance: interaction between genetic and environmental factors. Аnnu Rev Physiol 2002; 64: 877-897

3. Alvarez de la Rosa D, Canessa CM, Fyfe GK, Zhang P. Structure and regulation of amiloride-sensitive sodium channels. Annu Rev Physiol 2000; 62: 573-594

4. Kamynina E, Staub O. Concerted action of ENaC, Nedd4-2 and Sgk1 in transepithelial $\mathrm{Na}(+)$ transport. Am $J$ Physiol Renal Physiol 2002; 283: F377-F387

5. Webster MK, Goya L, Ge Y, Maiyar AC, Firestone GL. Characterization of sgk, a novel member of the serine/threonine protein kinase gene family which is transcriptionally induced by glucocorticoids and serum. Mol Cell Biol 1993; 13: 2031-2040

6. Kobayashi T, Cohen P. Activation of serum- and glucocorticoidregulated protein kinase by agonists that activate phosphatidylinositide 3-kinase is mediated by 3-phosphoinositide-dependent protein kinase-1 (PDK1) and PDK2. Biochem J 1999; 339 [Pt 2]: 319-328

7. Park J, Leong ML, Buse P, Maiyar AC, Firestone GL, Hemmings BA. Serum and glucocorticoid-inducible kinase (SGK) is a target of the PI 3-kinase-stimulated signaling pathway. EMBO J 1999; 18: 3024-3033

8. Lang $\mathrm{F}$, Klingel $\mathrm{K}$, Wagner CA et al. Deranged transcriptional regulation of cell-volume-sensitive kinase hSGK in diabetic nephropathy. Proc Natl Acad Sci USA 2000; 97: 8157-8162

9. Busjahn A, Aydin A, Uhlmann R et al. Serum- and glucocorticoid-regulated kinase (SGK1) gene and blood pressure. Hypertension 2002; 40: 256-260

10. Buckalew VM Jr, Berg RL, Wang SR, Porush JG, Rauch S, Schulman G. Prevalence of hypertension in 1,795 subjects with chronic renal disease: the modification of diet in renal disease study baseline cohort. Modification of Diet in Renal Disease Study Group. Am J Kidney Dis 1996; 28: 811-821

11. Kooman JP, Leunissen KM, Luik AJ. Salt and hypertension in end-stage renal disease. Blood Purif 1998; 16: 301-311

12. Zaehner T, Plueshke V, Frey BM, Frey FJ, Ferrari P. Structural analysis of the $11 \beta$-hydroxysteroid dehydrogenase type 2 gene in end-stage renal disease. Kidney Int 2000; 58: 1413-1419

13. Lovati E, Richard A, Frey BM, Frey FJ, Ferrari P. Genetic polymorphisms of the renin-angiotensin-aldosterone system in end-stage renal disease. Kidney Int 2001; 60: 46-54 
14. Hayashi M, Tapping RI, Chao TH et al. BMK1 mediates growth factor-induced cell proliferation through direct cellular activation of serum and glucocorticoid-inducible kinase. $J$ Biol Chem 2001; 276: 8631-8634

15. Debonneville C, Flores SY, Kamynina E et al. Phosphorylation of Nedd4-2 by Sgk1 regulates epithelial $\mathrm{Na}(+)$ channel cell surface expression. EMBO J 2001; 20: 7052-7059

16. Perrotti N, He RA, Phillips SA, Haft CR, Taylor SI. Activation of serum- and glucocorticoid-induced protein kinase (Sgk) by cyclic AMP and insulin. J Biol Chem 2001; 276: 9406-9412

17. Lalouel JM, Rohrwasser A. Development of genetic hypotheses in essential hypertension. J Hum Genet 2001; 46: 299-306
18. Wulff P, Vallon V, Huang DY et al. Impaired renal $\mathrm{Na}(+)$ retention in the sgk1-knockout mouse. J Clin Invest 2002; 110 : $1263-1268$

19. Hummler E, Barker P, Gatzy J et al. Early death due to defective neonatal lung liquid clearance in alpha-ENaCdeficient mice. Nat Genet 1996; 12: 325-328

20. Berger S, Bleich M, Schmid W et al. Mineralocorticoid receptor knockout mice: pathophysiology of $\mathrm{Na}+$ metabolism. Proc Natl Acad Sci USA 1998; 95: 9424-9429

21. Waldegger S, Barth P, Raber G, Lang F. Cloning and characterization of a putative human serine/threonine protein kinase transcriptionally modified during anisotonic and isotonic alterations of cell volume. Proc Natl Acad Sci USA 1997; 94: 4440-4445

Received for publication: 13.10 .03

Accepted in revised form: 18.6 .04 